\title{
Effects of contact time of natural cu-zeolite on the growth of Streptococcus pyogenes and Pseudomonas aeruginosa
}

\author{
Erwid Fatchur Rahman ${ }^{*, * \star} \bowtie$, Bambang Dwirahardjo***, Poerwati Soetji Rahajoe ${ }^{* * *}$ \\ *Department of Oral and Maxillofacial Surgery, Faculty of Dentistry, Sultan Agung Islamic University, Semarang, Central Java, Indonesia \\ ${ }^{* *}$ Oral and Maxillofacial Surgery Specialty Program, Faculty of Dentistry, Universitas Gadjah Mada, Yogyakarta, Indonesia \\ ***Department of Oral and Maxillofacial Surgery, Faculty of Dentistry, Universitas Gadjah Mada, Yogyakarta, Indonesia \\ *JI Kaligawe Raya km 4, Semarang, Central Java, Indonesia; $\bowtie$ correspondence: erwid@unissula.ac.id
}

Submitted: $6^{\text {th }}$ November 2018; Revised: $2^{\text {th }}$ December 2018; Accepted: $3^{\text {rd }}$ May 2019

\begin{abstract}
Infection of a surgical wound due to bacteria is a major problem for surgical patients. Cu-zeolite is a material that can suppress bacterial growth with reversible cation characteristics and adsorption to be developed into non-toxic disinfectants for humans. Packaging uses filter paper to keep disinfectant solutions or instruments that will be sterilized clean. This study aimed to observe the effects of contact time of natural Cu-zeolite on the growth of Streptococcus pyogenes (S. pyogenes) and Pseudomonas aeruginosa ( $P$. aeruginosa) bacteria. An experimental research was simple randomized design. Cu-zeolite 10 grams were packaged in Whatman no 42 paper bags measuring $5 \times 5 \mathrm{~cm}^{2}$, contacted for 15,30 and 45 minutes in $99.5 \mathrm{ml}$ of distilled water exposed to $0.5 \times 10^{8} \mathrm{CFU} / \mathrm{ml}$ of $S$. pyogenes and P. aeruginosa. Subsequently, bacterial growth was calculated using total plate count method. The average growth of S.pyogenes for 15 , 30 and 45 minutes $(1840 \pm 571.236 \mathrm{CFU} ; 29 \pm 16.33 \mathrm{CFU}$ and $0 \mathrm{CFU})$ while $P$. aeruginosa was $(2776 \pm 725.277 \mathrm{CFU}$; $55 \pm 23.214 \mathrm{CFU}$ and $0 \mathrm{CFU}$ ) respectively. Based on the independent t-test on Cu-zeolite, the bacterial growth in the $15^{\text {th }}$ and $30^{\text {th }}$ minute contact between $S$. pyogenes and $P$. aeruginosa was significantly different $(p<0.001)$. Longer contact time of natural Cu-zeolite caused the greater decrease in the growth of bacteria, where the decrease in S.pyogenes bacterial growth was greater than $P$. aeruginosa in the $15^{\text {th }}$ and $30^{\text {th }}$ minute contact.
\end{abstract}

Keywords: decreased bacterial growth; length of contact; natural packaged Cu-zeolite; $P$. aeruginosa; S. pyogenes

\section{INTRODUCTION}

Postoperative infection is resulted from the presence of infectious bacteria in surgical wounds originating from surgical instruments or ward environments. Surgical wound infection is a major problem in surgical patients with the incidence of nosocomial infections amounting to 500,000 cases per year out of 27 million surgical procedures. ${ }^{1}$ Potential pathogenic bacteria in the oral cavity directly associated to the upper respiratory tract and nasal cavity allow microorganisms from these organs to enter the oral cavity penetrating or contaminating through sputum, wounds and saliva. The groups of $S$. pyogenes $(100 \%)$ and $P$. aeruginosa $(7.7 \%)$ have been found to be pathogenic, resulting in nosocomial and life-threatening infections for people with a low immune system. ${ }^{2}$

Antibacterial materials made from heavy metal alloys as carrier materials was developed at the beginning of the $21^{\text {st }}$ century. ${ }^{3}$ Such a carrier material is zeolite which has a porous structure combined with metal ions as antibacterial agent. ${ }^{4}$ Zeolite is a geological material that has reversible cation properties, is molecular sieve and has absorption properties to be developed into alternative raw materials for pharmaceutical industry products (drugs) especially as carriers with slow-release properties of heavy metal cations as antimicrobial agent. ${ }^{4}$ The absorption on the surface of the heavy metal occurs without changing the crystal structure, but only changing the physicochemical properties of the zeolite. ${ }^{5}$ One method to suppress bacterial growth is by coating the surface of zeolite with heavy metals such as $\mathrm{Ag}, \mathrm{Cu}, \mathrm{Zn}, \mathrm{Hg}, \mathrm{Sn}, \mathrm{Pb}$, $\mathrm{Bi}, \mathrm{Cd}, \mathrm{Cr}$ or $\mathrm{Ti}$, or $\mathrm{Cu}$ metal ions as used in this study. The use of $\mathrm{Cu}$ heavy metals has a broad spectrum as an antimicrobial agent, which in small amount can kill microbes. The presence of negative 
ion-charged bacteria causes the release of metal cations from zeolite crystals. Metal cations will be bound to bacterial cell membrane proteins. The interaction results in damaged bacterial cell wall. ${ }^{6}$

The slow-release mechanism occurs when zeolites release cations (re-exchange) of heavy metals bit by bit and interact with negatively charged bacterial cell membranes. ${ }^{7}$ The release of $\mathrm{Cu}$ metal ions can be caused by an interaction between $\mathrm{Cu}$ ions and sulfhydryl groups in bacterial cell membranes which causes the release of $\mathrm{Cu}$ bonds on zeolites and activates the oligodynamic mechanism. ${ }^{8}$

The release of metal ions from zeolites depends on the cations exchanged, the ionic strength of the solution and the selectivity of zeolites to enter or excrete cations. ${ }^{4}$ This slow-release mechanism of zeolite requires time to be able to release $\mathrm{Cu}$ ions to interact with bacteria. The research on the synthesis of $\mathrm{Cu}$ (II) / silica as an antibacterial material showed a decrease in bacterial concentration along with the increased time of $\mathrm{Cu}$ contact with bacteria. ${ }^{9}$

The exchange of these metal ions must be calculated. Lower copper concentration will result in a greater chance of zeolite contact with alkaline earth metal than $\mathrm{Cu}$, where higher concentration of copper triggers ion-exchange reactions to saturate and it will be difficult for the remaining metal ions to exchange. ${ }^{9}$ The recommended copper concentration is $0.1 \mathrm{M}-0.8 \mathrm{M} .{ }^{10}$

Packaging uses filter paper to keep the disinfectant solutions or instruments that will be sterilized clean. Whatman No. 42 filter paper includes quantitative filter paper, used for quantitative and gravimetric analysis, and has a pore diameter of 2.5 microns, capable of withstanding a flow pressure rate of $0.4 \mathrm{psi}\left(0.0281 \mathrm{~kg} / \mathrm{cm}^{2}\right)$, capable of withstanding a flow rate of 1870 seconds $/ 100 \mathrm{ml}$, with a thickness of 200 microns, and weight of 100 gram $/ \mathrm{m}^{2}$ paper. ${ }^{11}$ Zeolite in this study used a size of 100 mesh or equivalent to $0.149 \mathrm{~mm}$. This condition caused the zeolite to withstand in Whatman No. 42 packaging while the $\mathrm{Cu}$ cation could come out of the paper wrap.

Copper $(\mathrm{Cu})$ was chosen in this study because of having good antimicrobial properties, higher chemical stability and a lower price than silver or mercury. ${ }^{12}$ The use of zeolite as a carrier of active substances is expected to obtain disinfectant material that is able to control toxicity to humans or animals, not corrosive, biocompatible, stainfree, odorless, stable, easy to use, economical and able to maintain inactivation of microorganisms. ${ }^{13}$ This study aimed at finding out the effects of contact time $0.8 \mathrm{M}$ concentration of Cu-zeolite (the condition of non-dissolved Cu-zeolite) immersed in distilled water as a disinfectant for the growth of $S$. pyogenes and $P$. aeruginosa bacteria.

\section{MATERIALS AND METHODS}

This was an experimental research with a simple randomized design which was carried out in 2 stages, i.e: identifying natural zeolite rocks at the Central Laboratory of the Faculty of Geology, Universitas Gadjah Mada with XRD Bulk method and making natural Cu-zeolite in wrapping paper and testing the contact time of Cu-zeolite in wrapping paper against the growth of $S$. pyogenes and $P$. aeruginosa bacteria.

Zeolite from Gunungkidul, Yogyakarta was weighed to get 1000 grams and crushed by using a crusher to become powder. The zeolite powder that passed no. 100 sieve but did not pass the 200 sieve was weighed to obtain 100 grams. Heat activation of zeolite powder was done with an oven at $105^{\circ} \mathrm{C}$ for 24 hours to remove impurities and water in natural zeolite. $^{14}$

Making $\mathrm{CuCl}_{2} 0.8 \mathrm{M}$ solution was done by using 54.55 grams of $\mathrm{CuCl}_{2} \cdot 2 \mathrm{H}_{2} \mathrm{O}$ powder diluted by adding $400 \mathrm{ml}$ of distilled water in the next measuring flask, after which zeolite powder was activated with hot temperature mixed with $\mathrm{CuCl}_{2}$ $0.8 \mathrm{M}$ solution, then stirred and heated using heat magnetic stirrer for 3 hours. $\mathrm{CuCl}_{2} 0.8 \mathrm{M}$ zeolite solution was placed on a filter paper. The filter paper had a cone shape and placed in the Buchner funnel following the mouth of the funnel, then washed with distilled water.

Washing was done by running distilled water on $\mathrm{CuCl}_{2} 0.8 \mathrm{M} \mathrm{Cu}$-zeolite for 15 times to obtain a mixture of $0.8 \mathrm{M}$ natural $\mathrm{Cu}$-zeolite which was completely free from dirt and chlorine. Natural 
Cu-zeolite which was chlorine-free could be identified by giving $\mathrm{AgNO}_{3}$ solution as an indicator of the remaining natural Cu-zeolite irrigated by distilled water. ${ }^{14}$ The last step of making $0.8 \mathrm{M}$ natural $\mathrm{Cu}$-zeolite was drying process using an oven at $105^{\circ} \mathrm{C}$ for 24 hours. ${ }^{14}$

A total of 10 grams of natural Cu-zeolite was put into Whatmann bag No. 42 with a size of $5 \times 5 \mathrm{~cm}$ and closed using masking tape. Removal was done by syringe on bacterial suspension with Brown III $10^{8}$ $\mathrm{CFU} / \mathrm{ml}$ standard as much as $0.5 \mathrm{ml}$. The bacterial suspension was dropped in $99.5 \mathrm{ml}$ distilled water containing natural Cu-zeolite with wrapping paper. Growth on agar media was observed at the contact time of 15 minutes, 30 minutes and 45 minutes and the positive control of natural $\mathrm{Cu}$-zeolite without wrapping paper contacted by $S$. pyogenes and $P$. aeruginosa bacteria in 28 minutes (Figure 1). ${ }^{9}$ The number of bacterial colonies was counted by spreading method on PCA CM0325, incubation for 24 hours and counting the number of bacterial colonies by using bacterial visual field assistance. Data from the results of this study were tested using paired t-test and independent t-test.

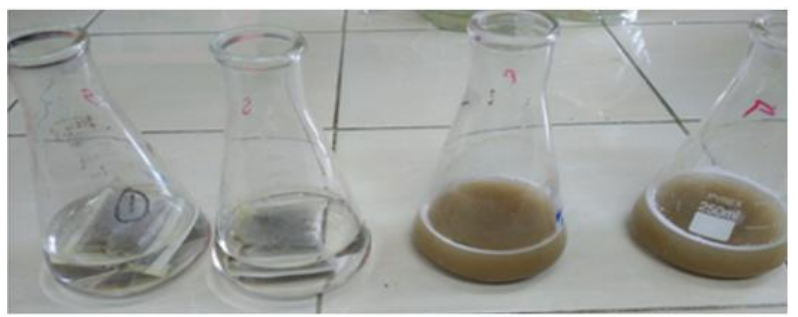

(A) Cu-zeolit with packaging

(B) Cu-zeolite without packaging

Figure 1. (A) Natural Cu-zeolite within wrapping paper and (B) Natural Cu-zeolite without packaging as a positive control

\section{RESULTS}

This study used Cu metal combined with zeolite of which the type and authenticity of the natural zeolite rocks were examined using XRD Bulk analysis at the geological technology center laboratory of Universitas Gadjah Mada, showing the type of mordenite natural zeolite. Next, testing the growth of natural Cu-zeolite bacteria against $S$. pyogenes and $P$. aeruginosa bacteria was done by comparing natural Cu-zeolite without packaging (positive control) which was carried out with variations in the length of contact time, i.e. 15, 30 and 45 minutes (Figure 2).

The observation of bacterial growth of $\mathrm{Cu}$ zeolite (Figure 3 and Table 1) showed a contact time of 15 and 30 minutes on $S$. pyogenes led to greater decrease than the same contact time on $P$. aeruginosa with the same pattern of decreased growth, while a contact time of 45 minutes and positive control in both $S$. pyogenes and $P$. aeruginosa bacteria resulted in no bacterial growth (0 CFU) with relatively stable graphical images.

Table 2 shows a summary of paired t-test duration of contact time of 15 minutes with 30 minutes on $S$. pyogenes and $P$. aeruginosa bacteria which showed significantly different results $(p<0.001)$ with a greater decrease in bacterial growth on a 30-minute contact with $S$. pyogenes and $P$. aeruginosa. Table 2 also showed that the contact time of 30 minutes for 45 minutes were different significantly $(p<0.001)$, $S$. pyogenes and $P$. aeruginosa.

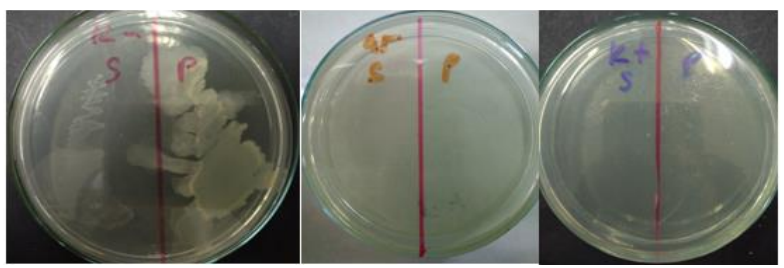

(A)

(B)

(C)

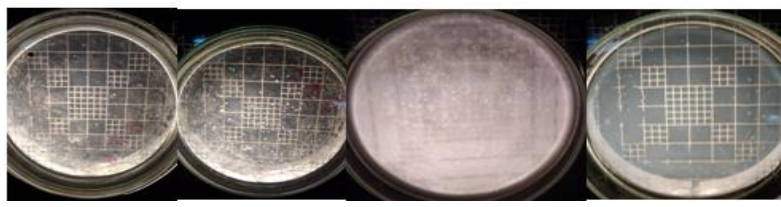

(D)

(E)

$(\mathrm{F})$

(G)

Figure 2. (A) Results of bacterial growth without $\mathrm{Cu}$ (negative control) (B) and (C) no bacterial growth was found in positive control and 45 minutes contact time (D) and (E) growth of $\mathrm{S}$. pyogenes bacteria at contact time of 30 minutes and 15 minutes with spread method $(F)$ and $(G)$ growth of $P$. aeruginosa bacteria in 15 and 30 minutes contact time with spread method

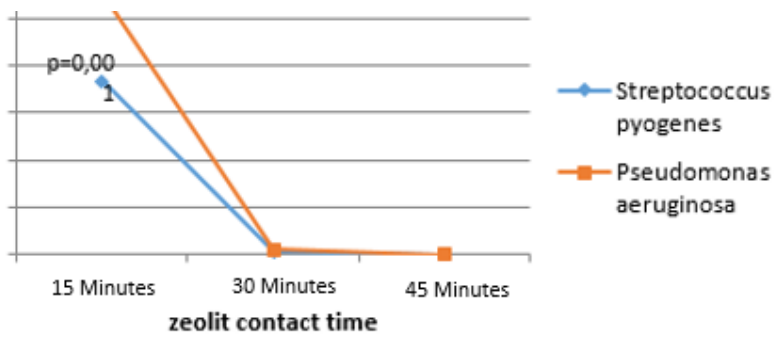

Figure 3. Graph of decreased growth of S. pyogenes and $P$. aeruginosa bacteria with contact time with paper-wrapped Cu-zeolite 
Majalah Kedokteran Gigi Indonesia. April 2020; 6(1): 25 - 31

ISSN 2460-0164 (print)

ISSN 2442-2576 (online)

Table 1. Mean and standard deviation (SD) of $S$. pyogenes and $P$. aeruginosa bacterial growth in natural $\mathrm{Cu}-$ zeolite with a concentration of $0,8 \mathrm{M}$ with various contact time

\begin{tabular}{|c|c|c|c|c|c|c|c|c|c|}
\hline \multirow{2}{*}{$\begin{array}{l}\text { Group of } \\
\text { Bacteria }\end{array}$} & \multirow[t]{2}{*}{$\mathrm{n}$} & \multicolumn{8}{|c|}{ Mean \pm SD and percentage of bacteria growth } \\
\hline & & W15 & $\%$ & W30 & $\%$ & W45 & $\%$ & Control & $\%$ \\
\hline S. pyogenes & 10 & $1840 \pm 571.236$ & 99.998 & $29 \pm 16.633$ & 99.9997 & 0 & 100 & 0 & 100 \\
\hline$P$. aeruginosa & 10 & $2776 \pm 725.277$ & 99.997 & $55 \pm 23.214$ & 99.9994 & 0 & 100 & 0 & 100 \\
\hline
\end{tabular}

Description, W15: contact time of 15 minutes, W30: contact time of 30 minutes, W45: contact time of 45 minutes, control: natural Cu-zeolite without packaging, \%: percentage of bacterial death, n: number of samples

Table 2. Summary of the results of paired t-test on variations of contact time of natural Cu-zeolite with $S$. pyogenes and $P$. aeruginosa

\begin{tabular}{ccccc}
\hline & & & p value \\
Group of bacteria & $\mathrm{n}$ & W 15-30 & W 15-45 & W 30-45 \\
\hline S. pyogenes & 10 & 0.001 & 0.001 & 0.001 \\
P. aeruginosa & 10 & 0.001 & 0.001 & 0.001 \\
\hline
\end{tabular}

Description: $\mathrm{n}$ : number of samples, W15-30: contact time of natural Cu-zeolite in the same bacteria in the $15^{\text {th }}$ and $30^{\text {th }}$ minute, W15-45: contact time of natural Cu-zeolite in the same bacteria in the $15^{\text {th }}$ and $45^{\text {th }}$ minute, W30-45: contact time of natural Cu-zeolite in the same bacteria in the $30^{\text {th }}$ and $45^{\text {th }}$ minute.

Table 3. Comparison results of the growth of $S$. pyogenes with $P$. aeruginosa against Cu-Zeolite the same contact

\begin{tabular}{|c|c|c|c|c|c|c|c|}
\hline \multirow[b]{2}{*}{ Group of bacteria } & \multirow[b]{2}{*}{$\mathrm{n}$} & \multicolumn{6}{|c|}{ Independent t-test } \\
\hline & & $\begin{array}{r}\text { W15 } \\
\times \pm S D \\
\end{array}$ & $p$ value & $\begin{array}{c}\text { W30 } \\
x \pm S D \\
\end{array}$ & $p$ value & $\begin{array}{c}\text { W45 } \\
X \pm S D \\
\end{array}$ & $p$-value \\
\hline S. pyogenes & 10 & $1840 \pm 571.236$ & 0.005 & $29 \pm 16.633$ & 0.01 & 0 & 1.00 \\
\hline$P$. aeruginosa & 10 & $2776 \pm 725.277$ & & $55 \pm 23.214$ & & 0 & \\
\hline
\end{tabular}

Description: W15: 15-minute contact time, W30: 30-minute contact time W45: 40-minute contact time: $X \pm$ SD: mean and standard deviation, n: number of samples

The results of the independent t-test (Table 3 ) on the comparison of bacterial growth with 15-minute contact time between $S$. pyogenes and $P$. aeruginosa showed significant differences $(p<0.005)$ with a greater decrease in $S$. pyogenes growth (1840 CFU) compared to $P$. aeruginosa growth (2776 CFU); with the contact time of 30 minutes, the decreased growth of $S$. pyogenes bacteria was $29 \mathrm{CFU}$ compared to that of $P$. aeruginosa (55 CFU); with 45-minute contact time, S.pyogenes and $P$. aeruginosa showed no significant difference $(p=1.00)$ with bacterial growth of $0 \mathrm{CFU}$.

\section{DISCUSSION}

Research on Cu-zeolite mostly examined bacterial contamination in water like the one by Rossainz ${ }^{15}$ on the effects of Cu-zeolite and Ag-zeolite as antibacterial agents in water contamination by
E. coli and C. albicans. A research by $\mathrm{Lin}^{16}$ on $\mathrm{Cu}-$ zeolite as a filter media and antibacterial agent against $E$. coli in rainfed region. As observed, the use of Cu-zeolite has never been used as a disinfectant in some previous studies related to bacterial inhibition with decreasing results graded from Escherichia coli, Candida albicans, Candida glabrata, Staphylococcus aureus, Pseudomonas aeruginosa, Bacillus cereus, Aspergillus niger, to Penicillium vinaceum in polluted environments. ${ }^{17}$

Inhibition against $S$. pyogenes has never been studied. In the human body, it is estimated that there is normally between $5-15 \%$ of $P$. aeruginosa and $S$. pyogenes located in the respiratory tract and they are one of the most common causes of nosocomial infections. ${ }^{8}$ Data in the causes of nosocomial infections showed that $S$. pyogenes in Kandou General Hospital was reported at $11.1 \%$, GB pant Hospital at $1.6 \%$, and RPI for pediatric 
hospital in Jakarta at 5.1\%, while $P$. aeruginosa at Kandou Hospital was at $46 \%$, and Abdoel Moeloek Hospital was at $29 \%$. This study also showed that Cu-zeolite can be used to kill $S$. pyogenes and $P$. aeruginosa bacteria. ${ }^{18}$

There was no research on the contact time of Cu-zeolite against $S$. pyogenes and $P$. aeruginosa bacteria, but previous studies by $\mathrm{Li}^{14}$ focused on the inhibition of Cu-zeolite against $E$. coli bacteria (gram-negative) in rainwater with a 9-minute contact of Cu-zeolite, showing ability to reduce $E$. coli by 1.7 log, contact time about \pm 31 minutes killed a total of $10^{6}$ bacteria. Another study by Mazolla ${ }^{19}$ showed that decimal time reduction of $\mathrm{Cu}$ (II) zeolite testing on $E$. coli for 0.6 minutes or about \pm 3.6 minutes was able to kill a total of $10^{6}$ bacteria. The length of contact time of Cu-zeolite studied by the author was longer than those of previous research, and it is likely because the use of different types of bacteria and non-dispersed packaged Cu-zeolite prolonged the inhibitory power or the ability to kill bacteria.

The $15^{\text {th }}$ and $30^{\text {th }}$ minute of contact time of natural Cu-zeolite was able to reduce the growth of $S$. pyogenes and $P$. aeruginosa bacteria up to $99.9 \%$. Decreased growth in $S$. pyogenes was greater than that in $P$. aeruginosa in the 15 and 30 minutes of contact time. The differences in the number of bacteria inhibited at this time of contact can be caused by differences in Cu toxicity to these bacteria, due to differences in the mechanism of toxicity to bacteria, or the anatomical differences in these microorganisms. ${ }^{20}$

The structure of the cytoplasmic membrane and bacterial cell wall between gram-positive and negative is different. More complex wall of negative gram bacteria than positive gram bacteria affects the sensitivity of bacterial cells in binding to heavy metals, so the cell walls of positive gram bacteria are more easily damaged when compared to those of negative gram bacteria. ${ }^{20,21}$

The growth of S. pyogenes and $P$. aeruginosa decreased along with the length of time of bacterial contact. The results of this study are in accordance with Kawasaki ${ }^{22}$ that the decrease in microorganisms occurred after contact with a combination of heavy metals and zeolites in a certain period of time, showing the release of $\mathrm{Cu}$ in zeolite, and indicating the time of release of heavy metals by zeolites to interact with bacteria. The release of heavy metals slowly forms a pattern of bacterial growth which decreases along the length of contact time.

Natural Cu-zeolite with packaging was able to kill all bacteria in the $45^{\text {th }}$ minute of contact time and there was no difference with the positive control. The packaging of natural Cu-zeolite took longer to kill bacteria because it took time to release natural Cu-zeolite bonds even though the bond between $\mathrm{Cu}$ and zeolite was weak. As observed, several references support the release of heavy metals in zeolite such as previous research by Niira, ${ }^{10}$ claiming that the amount of $\mathrm{Ag}$ ions released from Ag-zeolite in water flowing is very low, $1 \mathrm{ppb}$ to 3 ppb. Research on Ag-zeolite immersed in distilled water for 24 hours did not show the presence of $\mathrm{Ag}$ ions released into distilled water. ${ }^{15} \mathrm{Cu}$ ions in Cu-zeolite bonds in paper-wrapped flowing with distilled water are released into the distilled water of less than $2 \mathrm{mg} / \mathrm{L} .{ }^{14}$ This indicates that energy is needed to break the bond between $\mathrm{Cu}$ and zeolite to extend the contact time with negatively charged bacteria to attract $\mathrm{Cu}$ from zeolite.

The test of the contact time of $S$. pyogenes and $P$. aeruginosa bacteria on the positive control (natural Cu-zeolite without wrapping paper) showed significant differences between the length of contact time of 15 minutes and 30 minutes, while the contact time of 45 minutes for the control was not significant. It corresponds to the study by Hrenovic ${ }^{23}$ stating that $\mathrm{Cu}$ interaction with bacteria can occur because $\mathrm{Cu}^{2+}$ ions are released from natural $\mathrm{Cu}$-zeolite in the media and in contact with natural $\mathrm{Cu}$-zeolite powder containing $\mathrm{Cu}$ metal ions. This condition causes the release of $\mathrm{Cu}$ ions to liquid media from natural Cu-zeolite towards bacteria due to the attraction of bacteria whose surface is negatively charged so the bacteria actively take heavy metal ions from zeolite. The paper-wrapped natural zeolite also causes longer contact time to inhibit or to kill bacteria which makes natural Cuzeolite not dispersed in solution thus taking longer time to interact.

This study concludes that the longer the contact time of natural $\mathrm{Cu}$-zeolite at a concentration 
of $0.8 \mathrm{M}$ as disinfectant material, the greater the decrease in the growth of $S$. pyogenes and $P$. aeruginosa bacteria, with a greater decrease in $S$. pyogenes bacteria growth compared to that of $P$. aeruginosa in the $15^{\text {th }}$ and $30^{\text {th }}$ minute and able to kill all $S$. pyogenes and $P$. aeruginosa bacteria in the $45^{\text {th }}$ minute of contact time.

\section{REFERENCES}

1. Kangau Z, Odhiambo E. Orthopedic and trauma nurses views on causes and prevention of surgical site infection SSI's; School of Health and Social Studies; JAMK University of Applied Sciences; 2009.

2. Ghahramanloo A, Sadhegian A, Sohrabi K, Bidi A. A microbiologic investigation following the desinfection of irreversible hydrocolloid materials using the spray method. J Calif Dent Assoc. 2009; 37(7): 471-477.

3. Brett ME, Lackey L, McCreanor P. The influence of metalic biocid concentration on the deactivation rate of Coliform in river water. ASEE Southeast Section Conference. American Society for Engineneering Education; 2014.

4. Orha C, Likarec M, Pode R, Burtica G. Studies regarding copper recovery from residual solution on natural zeolites. Chem. Bull. "Politechnica" Univ. (Timisoara). 2005; 50(64): 152-154.

5. Fatimah D. Modifikasi zeolit alam melalui penanaman inhibitor cu dengan metode batch sebagai bahan baku obat antiseptik. Bandung: Seminar Nasional Zeolit VI; 2009. 75.

6. Hobman JL, Crossman LC. Bacterial antimicrobial metal ion resistance. J Med Microbiol. 2015; 64(5): 471-497.

doi: 10.1099/jmm.0.023036-0

7. Rodriguez-Iznaga I, Petranovskii V, Rodriguez-Fuentes G, Bogdanchikova N, Avalos M. Modification of mordernite and natural clinoptilolite by copper: role of drying temperature. Studies In Surface Science and Catalysis. 2001; 135: 212. doi: 10.1016/S0167-2991(01)81425-7

8. Borkow G, Gabbay J. Copper as a biocidal tool. Curr Med Chem. 2005; 12(18): 216321675. doi: $10.2174 / 0929867054637617$

9. Tania L, Wijaya K, Trisunaryanti W. Sintesis $\mathrm{Cu}(\mathrm{II}) / \mathrm{Silika}$ dengan metode sol-gel sebagai antibakteri terhadap Escherichia coli dan Staphylococcus aureus. Berkala MIPA. 2014; 24(2); 122-135.

10. Niira $R$, Niira $Y$, Niira $H$, Yamamoto $T$, Uchida M. Antibiotic zeolite, United state patent Document no. 4938958; 1990.

11. Sandi DMN, Indarto, Bayuaji R, Ekaputri JJ. Study of using paper filter whatman no.42 for measuring water retention in cement paste. The Journal for Technology and Science. 2016; 27(3): 59-65.

doi: 10.12962/j20882033.v27i3.1905

12. Nolte WA. Oral Microbiology, $4^{\text {th }}$ ed. St. Louis: The CV Mosby Co; 1982. 68-75, 287, 302-5, 523-532.

13. Butcher W, Ulaeto. Contact inactivation of orthopoxviruses by household desinfectans. Journal of Applied Microbiology. 2005; 99(2): 279-284.

doi: 10.1111/j.1365-2672.2005.02601.x

14. Li B, Yu S, Hwang JY, Shi S. Antimicrobial vermiculit nanomaterial. $J$ of Mineral and Material Characteristization and Engineering. 2002; 1(1): 61-67.

15. Rossainz-Castro LG, Gomez, De-La-Rosa, Olguin, MT, Alcantara-Diaz. Comparison between silver- and copper- modified zeoliterich tuffs as microbicide agents for Escherichia coli and Candida Albicans. 2016. Diunduh dari http://www.ncbi.nlm.nih.govm/pubmed pada 15 Mei 2018.

16. Lin $\mathrm{H}, \mathrm{Li} \mathrm{TX}$, Zong $\mathrm{C}$, Wang $\mathrm{S}$. The preparation and application of the bacteriostatic inorganic materials for environment decontamination. Beijing: Proceeding German-Chinese-Polish Symposium Environmental Engineering. 2003; 291(4): 579-590.

17. Demirci S, Ustaoglu Z, Yilmazer GA, Sahin F, Bac N. Antimicrobial properties of zeolite-X 
and zeolite-A ion-exchanged with silver, copper, and zink against a broad range of microorganism. Appl Biochem Biotechnol. 2014; 172(3): 1652-1662.

doi: $10.1007 /$ sl2010-013-0647-7

18. Baharutan A, Rares FES, Soelingan S. Pola bakteri penyebab infeksi nosokimial pada ruang perawatan intensif anak di BLU RSUP Prof. Dr. R. D. Kandou Manado. Jurnal e-Biomedik. 2015; 3(1); 45-53.

doi: 10.35790/ebm.3.1.2015.7417

19. Mazzola PG, Jozala AF, Novaes LCdL, Moriel $P$, Penna TCV. Minimal inhibitory concentration (MIC) determination of disinfectant and/or sterilizing agents. Braz. J. Pharm. Sci. 2009; 45(2); 241-248. doi: 10.1590/S1984-82502009000200008

20. Brooks GF, Butel JS, Morse SA. Mikrobiologi kedokteran jawetz. Melnick \& Adelberg, Terj. Hartanto. Ed.23. Jakarta: EGC; 2008. 1-67,
635-58.

21. Suhendrayatna. Bioremoval logam berat dengan menggunakan mikroorganisme: suatu kajian kepustakaan. Seminar Bio Teknologi. Tokyo: Sinergi Forum-Institut of Technology; 2001.

22. Kawasaki K, Masahiro K, Fujitani T. Denture detergents containing antimicobial metal ions. United State Patent No 6468950 BI; 2002.

23. Hrenovic J, Milenkovic J, Ivankovic T, Rajic N. Antibacterial activity of heavy metalloaded natural zeolite. Journal of Hazardous Materials. 2012; 201-202: 260-264. doi: 10.1016/j.jhazmat.2011.11.079 